\title{
Aldehyde dehydrogenase activity in Lactococcus chungangensis: Application in cream cheese to reduce aldehyde in alcohol metabolism
}

\author{
Maytiya Konkit, Woo Jin Choi, and Wonyong Kim ${ }^{1}$ \\ Department of Microbiology, Chung-Ang University College of Medicine, Seoul 06974, Republic of Korea
}

\begin{abstract}
Previous studies have shown that the metabolic capability of colonic microflora may be at least as high as that of the liver or higher than that of the whole human body. Aldehyde dehydrogenase (ALDH) is an enzyme produced by these bacteria that can metabolize acetaldehyde, produce from ethanol to acetate. Lactococcus species, which is commonly used as a starter in dairy products, was recently found to possess the ALDH gene, and the activity of this enzyme was determined. In this study, the ALDH activity of Lactococcus chungangensis CAU $28^{\mathrm{T}}$ and 11 other type strains in the genus Lactococcus was studied. Only 5 species, 3 of dairy origin (Lactococcus lactis ssp. lactis KCTC $3769^{\mathrm{T}}$, Lactococcus lactis ssp. cremoris KCCM $40699^{\mathrm{T}}$, and Lactococcus raffinolactis DSM $20443^{\mathrm{T}}$ ) and 2 of nondairy origin (Lactococcus fujiensis $\mathrm{NJ}^{\mathrm{N}} 17^{\mathrm{T}}$ and L. chungangensis CAU $28^{\mathrm{T}}$ ), showed ALDH activity and possessed a gene encoding ALDH. All of these strains were capable of making cream cheese. Among the strains, $L$. chungangensis produced cream cheese that contained the highest level of ALDH and was found to reduce the level of acetaldehyde in the serum of mice. These results predict a promising role for $L$. chungangensis CAU $28^{\mathrm{T}}$ to be used in cheese that can be developed as functional food.
\end{abstract}

Key words: Lactococcus, alcohol metabolism, acetaldehyde, aldehyde dehydrogenase

\section{INTRODUCTION}

Lactococcus is well known and widely used in fermentation of foods such as cheese, yogurt, kefir, and butter. Lactococcus species are wildly used as starter in the production of cheese such as Cheddar (Madkor et al., 2000) and Parmesan (Fenster et al., 2003). Mixed-strain mesophilic cultures mainly consist of Lactococcus lactis ssp. lactis and L. lactis ssp. cremoris, which provide the

Received October 21, 2015.

Accepted November 15, 2015.

${ }^{1}$ Corresponding author: kimwy@cau.ac.kr primary acid-producing function during fermentation and also contribute to cheese ripening through production of enzymes related to proteolysis and conversion of AA into flavor compounds (Fox and Wallace, 1997). Lactococcus raffinolactis has also been found to play an important role in production of Moroccan soft white cheese, a traditional dairy product from Morocco (Ouadghiri et al., 2005). Lactococci have several other metabolic properties; mesophilic cultures are famously used in the production of Cheddar, Gouda, Edam, blue, Camembert, and cream cheese (Beresford et al., 2001). Cream cheese is a soft, fresh, acid-coagulated cheese produced by acidification by Lactococcus, used as a mesophilic lactic acid starter (Guinee et al., 1993). This type of cheese is available worldwide and is very popular in North America. It is used in several kinds of desserts, such as cheesecake, in salad dressings, and as a spread on bagels or bread. Moreover, the market share of this cheese increased from 7 to $17 \%$ between 2001 and 2005 (Bourroul, 2006). Because it is simple to manufacture and because it requires no ripening step and is processed using only whole milk enriched with cream and starter, cream cheese has been the object of much research (Buriti et al., 2007; Coutouly et al., 2014; Silva et al., 2014).

Acetaldehyde is a product of the metabolism of ethanol by many intracolonic microbes and also by the colonic mucosal cells (Salaspuro, 1998). Indeed, many aerobic bacteria representing the normal flora of the human large intestine possess significant cytosolic $\mathrm{NADP}^{+}$- and $\mathrm{NAD}^{+}$-dependent aldehyde dehydrogenase activity (Nosova et al., 1996). In accordance with their aldehyde dehydrogenase activity, these bacteria metabolize acetaldehyde to acetate. Aldehyde dehydrogenases (ALDH) are the group of enzymes catalyzing the conversion of aldehyde to corresponding acids by means of a virtually irreversible, $\mathrm{NAD}^{+}$-dependent reaction and are present in a wide range of organisms, from bacteria to humans (Yoshida et al., 1998).

In recent decades, consumers have begun to demand foods that contribute directly to their health. Today, food not only satisfies hunger and provides necessary nutrients, but also prevents nutrition-related disease 
and improves the physical and mental well-being of humans (Roberfroid, 2002; Menrad, 2003). Cheese is a fermented food that is produced by microorganisms, such as lactic acid bacteria, which play a vital role in producing the physiochemical, sensory, nutritional, preservability, and safety characteristics of the final product, and which also act as probiotics for human health. The ALDH activity of lactococci, especially Lactococcus chungangensis, in cheese has only recently been shown; cheese can be a source of ALDH, which can decrease aldehyde levels in the human body, indicating that it shows potential to become a new choice as a functional food.

Lactococcus chungangensis $\mathrm{CAU} 28^{\mathrm{T}}$ is a strain of Lactococcus spp. that is of nondairy origin; it was isolated from activated sludge (Cho et al., 2008). Previous studies have shown that it exhibits activity of several beneficial enzymes, such as aldehyde dehydrogenase (Konkit et al., 2014, 2015). The objective of the present study was to evaluate the potential ALDH activity of L. chungangensis in both cheese and in vivo compared with other lactococci cultures, such as L. lactis ssp. lactis, L. lactis ssp. cremoris, and L. raffinolactis, which are routinely used in the dairy industry.

\section{MATERIALS AND METHODS}

\section{Bacterial Strains Cultured}

Lactococcus chungangensis $\mathrm{CAU} 28^{\mathrm{T}}(=\mathrm{KCTC}$ $\left.13185^{\mathrm{T}}\right)$, L. lactis ssp. lactis KCTC $3769^{\mathrm{T}}$, L. lactis ssp. cremoris KCCM $40699^{\mathrm{T}}$, L. lactis ssp. hordiniae KCTC $3768^{\mathrm{T}}$, L. lactis ssp. tructae NBRC $110453^{\mathrm{T}}$, L. raffinolactis DSM $20443^{\mathrm{T}}$, Lactococcus garvieae KCTC $3772^{\mathrm{T}}$, Lactococcus piscium DSM 6634 ${ }^{\mathrm{T}}$, Lactococcus plantarum DSM $20686^{\mathrm{T}}$, Lactococcus taiwanensis NBRC $109049^{\mathrm{T}}$, Lactococcus formosensis NBRC $109475^{\mathrm{T}}$, and Lactococcus fujiensis DSM $27937^{\mathrm{T}}$ were cultured in tryptic soy broth (Becton, Dickinson and Company, East Rutherford, NJ) at $30^{\circ} \mathrm{C}$ for $24 \mathrm{~h}$. Strains were obtained from the Korean Collection for Type Cultures (KCTC; Taejon, South Korea), the Korean Culture Center of Microorganisms (KCCM; Seoul, South Korea), the Deutsche Sammlung von Mikroorganismen und Zellkulturen (DSM; Braunschweig, Germany), the National Biological Resource Center (NBRC; Tokyo, Japan), and the Culture Collection, University of Göteborg (CCUG; Göteborg, Sweden).

\section{ALDH Gene and Primer Design}

Genomic DNA was then extracted using an i-genomic BYF DNA Extraction Mini Kit (iNtRON Biotechnology, Seoul, Korea). Primers for amplification of the genes encoding ALDH were designed using PRIMER3 software (http://bioinfo.ut.ee/primer3-0.4.0/), based on the gene sequence of $L$. chungangensis CAU $28^{\mathrm{T}}$. The primer sequences were as follows: forward = 5'-GTTGCCATCATTGACACTTGGT-3', and reverse $=5^{\prime}$-AGGAATGTTCCAAGCACCAC-3'. The total volume of the PCR reaction mixture was $20 \mu \mathrm{L}$, and consisted of $5 \mathrm{U}$ of Taq DNA polymerase (Beams Biotechnology, Seongnam, South Korea), $2.0 \mu \mathrm{L}$ of 10 $\times$ Taq buffer, $1 \mu \mathrm{L}$ of deoxynucleotide triphosphates (dNTP) mixture, $1 \mu \mathrm{L}$ of each primer, and $3 \mu \mathrm{L}$ of genomic DNA as the template. Amplifications were performed in a TProfessional Thermocycler (Biometra GmbH, Göttingen, Germany) as follows: an initial cycle of $95^{\circ} \mathrm{C}$ for $5 \mathrm{~min}, 30$ cycles of denaturation at $95^{\circ} \mathrm{C}$ for $1 \mathrm{~min}$, annealing at $55^{\circ} \mathrm{C}$ for $1 \mathrm{~min}$, and extension at $72^{\circ} \mathrm{C}$ for $1 \mathrm{~min}$, and a final extension at $72^{\circ} \mathrm{C}$ for 10 min. After PCR amplification, $3 \mu \mathrm{L}$ of each PCR product were run on a $1.2 \%$ Seakem LE agarose gel (FMC Bioproducts, Rockland, ME) and visualized with a Gel DOC XR ${ }^{+}$Imaging system (Bio-Rad Laboratories, Hercules, CA). The PCR products were sequenced using a BigDye Terminator Cycle Sequencing kit and an automatic DNA sequencer (model 3730; Applied Biosystems, Foster City, CA).

\section{Cream Cheese Production}

Pasteurized milk (Pasteur Milk Co., Ltd., Seoul, South Korea) from a local market was heated at $68^{\circ} \mathrm{C}$ for $30 \mathrm{~min}$, then cooled, and inoculated with a $5 \%$ (vol/ vol) Lactococcus starter and incubated for $48 \mathrm{~h}$ (acidified milk). This mixture was stirred and heated at $70^{\circ} \mathrm{C}$ for $5 \mathrm{~min}$, then the whey was separated using a cloth bag, and the curd was set and drained of water by adding $0.5 \%$ salt. Finally, the cream cheese samples were freeze-dried and stored in the dark at $4^{\circ} \mathrm{C}$ until further testing.

\section{In Vitro Assay of ALDH Activity}

A modified version of a previously published method (Tottmar et al., 1973) was used to identify ALDH activity. Briefly, ALDH activity was determined enzymatically using a reaction mixture containing $1.0 \mathrm{M}$ Tris/ $\mathrm{HCl}$ buffer (pH 8.0), $20 \mathrm{~m} M \mathrm{NAD}^{+}, 3.0 \mathrm{M} \mathrm{KCl}$, $0.33 M$ 2-mercaptoethanol, and $1.0 M$ acetaldehyde in a final volume of $3.0 \mathrm{~mL}$. The ALDH activity of baker's yeast, Saccharomyces cerevisiae (Sigma-Aldrich, Madison, WI), was used for calibration. The ALDH activity of the bacterial strains was determined using $1 \mathrm{~mL}$ of 1 $\times 10^{6}$ cells of each Lactococcus strain, in triplicate; cells were added to the reaction mixture and incubated at $30^{\circ} \mathrm{C}$ for $5 \mathrm{~min}$. The absorbance was measured at 340 
$\mathrm{nm}$ and compared with a standard curve to determine ALDH levels. For cream cheese samples, $10 \mathrm{mg} / \mathrm{mL}$ of each cream cheese sample was added and the reaction mixture was incubated at $30^{\circ} \mathrm{C}$ for $5 \mathrm{~min}$. The absorbance was measured at $340 \mathrm{~nm}$ and compared with a standard curve.

\section{In Vivo Assay of ALDH Activity}

Animal Administrations. Because levels of ALDH activity in cream cheese were higher than those in cell culture, cream cheese was used to determine the effects of ALDH activity on acetaldehyde levels in mouse blood. Seven-week-old male Imprinting Control Region (ICR) mice were purchased from Samtako (Samtako, Osan, South Korea). For 1 wk before the experiments, mice were acclimatized in cages at $22^{\circ} \mathrm{C}$ under a 12 -h day/night cycle; these conditions were maintained throughout the experiment. The mice were divided into 7 groups ( $\mathrm{n}=5$ for each group) based on cream cheese sample treatment, as follows: (1) normal (untreated) group; (2) control (ethanol) group; (3) cream cheese made with L. chungangensis CAU $28^{\mathrm{T}}(100 \mathrm{mg} / \mathrm{kg})$ group; (4) cream cheese made with $L$. fujiensis DSM $27937^{\mathrm{T}}(100 \mathrm{mg} / \mathrm{kg})$ group; (5) cream cheese made with L. lactis ssp. cremoris KCCM $40699^{\mathrm{T}}(100 \mathrm{mg} / \mathrm{kg})$ group; (6) cream cheese made with L. lactis ssp. lactis KCTC $3769^{\mathrm{T}}$ (100 mg $\left./ \mathrm{kg}\right)$ group; (7) cream cheese made with L. raffinolactis DSM $20443^{\mathrm{T}}(100 \mathrm{mg} / \mathrm{kg})$ group. Prior to the test, mice were fasted from food for $18 \mathrm{~h}$. Ethanol or the cream cheese sample was orally administered. Mice were gavaged with $22 \%$ ethanol (2 $\mathrm{g}$ of ethanol $/ \mathrm{kg}$ of BW).

Determination of Blood Alcohol and Acetaldehyde Concentrations in Mice. Whole-blood samples were collected from the tail vein of the experimental ICR mice using a serum separation tube at 1, 3, 5, and $7 \mathrm{~h}$ after the acetaldehyde challenge. After incubation at $4^{\circ} \mathrm{C}$ for $10 \mathrm{~min}$, the blood samples were centrifuged at $1,500 \times g$ for $15 \mathrm{~min}$ at $4^{\circ} \mathrm{C}$. The supernatant, which consisted of serum, was used in the analysis of blood alcohol and acetaldehyde levels. The reaction mixture contained $0.3 \quad M \quad \mathrm{KH}_{2} \mathrm{PO}_{4}$ buffer ( $\mathrm{pH}$ 9.0), $49 \mathrm{mM}$
$\mathrm{NAD}^{+}$, and a serum sample in a final volume of 3.0 $\mathrm{mL}$. The reaction mixture was incubated at $20^{\circ} \mathrm{C}$ for $5 \mathrm{~min}$. The absorbance was measured at $340 \mathrm{~nm}$ using a spectrophotometer (A1). After the measurement, 50 $\mu \mathrm{L}$ of $\mathrm{ALDH}$ was added and incubated at $20^{\circ} \mathrm{C}$ for 5 min. The absorbance was measured at $340 \mathrm{~nm}$ using a spectrophotometer (A2). The blood acetaldehyde concentration was calculated as a percentage using the following equation:

$$
\text { Concentration }=0.7158 / 3.6 \times \Delta \mathrm{A},
$$

where $\Delta \mathrm{A}=$ sample $(\mathrm{A} 2-\mathrm{A} 1)-\operatorname{blank}(\mathrm{A} 2-\mathrm{A} 1)$.

\section{Statistical Analysis}

All measurements are expressed as the mean \pm standard deviation and were performed in triplicate. Statistical analyses of the differences between samples were performed using one-way ANOVA, followed by a post-hoc multiple comparison using the Duncan and $t$-tests in the Predictive Analytics Software (PASW) statistics package for Windows program (Microsoft Corp., Redmond, WA). Differences of $P<0.01$ were considered to be statistically significant.

\section{RESULTS}

\section{Detection of Genes Encoding ALDH}

The ALDH enzymes showed a broad range of substrate specificity for aliphatic and aromatic aldehydes, and ALDH enzymes have been identified in animals, fungi, and bacteria. The effect of cream cheese produced using Lactococcus strains on metabolism of alcohol to aldehyde was determined by measuring the generation of reduced NADH (Figure 1). A PCR, using newly designed ALDH primers, was used to identify the presence of genes encoding ALDH in all 9 species and 4 subspecies of Lactococcus. Only 5 strains - L. chungangensis CAU $28^{\mathrm{T}}$, L. fujiensis DSM $27937^{\mathrm{T}}$, L. lactis ssp. cremoris KCCM $40699^{\mathrm{T}}$, L. lactis ssp. lactis KCTC $3769^{\mathrm{T}}$, and L. raffinolactis DSM $20443^{\mathrm{T}}$ — were found to

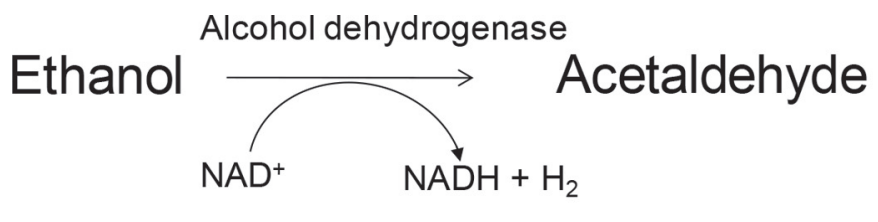

Aldehyde dehydrogenase

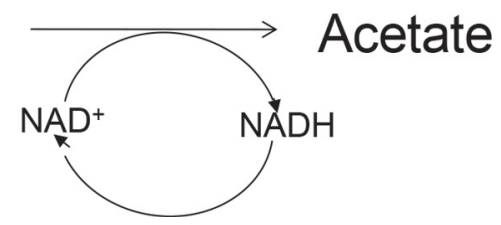

Figure 1. The chemical reaction of alcohol (ethanol) and aldehyde metabolism. 
possess an ALDH gene, indicated by a strong band in the gel (953 bp in size; Figure 2).

\section{Cream Cheese Production}

Cream cheese was made using Lactococcus spp., such as L. chungangensis CAU $28^{\mathrm{T}}$, L. fujiensis DSM $27937^{\mathrm{T}}$, L. lactis ssp. cremoris KCCM $40699^{\mathrm{T}}$, L. lactis ssp. lactis KCTC $3769^{\mathrm{T}}$, and L. raffinolactis DSM $20443^{\mathrm{T}}$. All strains were found to be suitable as starter cultures, and caused coagulation and acidification of the milk mixture during the cheese manufacturing process. All cream cheeses had a smooth, soft, mild, rich, and creamy white texture.

\section{In Vitro Assay of ALDH Activity}

The ALDH activity of cells grown in tryptic soy broth was determined by measuring the generation of reduced NADH. Lactococcus chungangensis CAU $28^{\mathrm{T}}$ showed the highest ALDH activity of all Lactococcus strains, at $45.9 \mathrm{nmol} / \mathrm{min}$ per gram; L. lactis ssp. cremoris $\mathrm{KCCM}$ $40699^{\mathrm{T}}$, L. lactis ssp. lactis KCTC $3769^{\mathrm{T}}$, L. fujiensis DSM $27937^{\mathrm{T}}$, and L. raffinolactis DSM $20443^{\mathrm{T}}$ showed ALDH activity levels of $40.8,37.9,33.4$, and $30.2 \mathrm{nmol} /$ min per gram, respectively (Figure $3 \mathrm{~A}$ ).

In vitro studies were performed to evaluate the effect of cream cheese made using Lactococcus strains on 1 of the 2 key chemical reactions of alcohol metabolism by ALDH. Lactococcus chungangensis CAU $28^{\mathrm{T}}$ showed the highest level of ALDH activity, at $74.2 \mathrm{nmol} / \mathrm{min}$ per gram, followed by L. lactis ssp. cremoris KCCM $40699^{\mathrm{T}}$, L. lactis ssp. lactis KCTC $3769^{\mathrm{T}}$, L. raffinolactis DSM $20443^{\mathrm{T}}$, and L. fujiensis DSM $27937^{\mathrm{T}}$, which showed ALDH activities of 54.0, 53.6, 48.6, and 47.4 $\mathrm{nmol} / \mathrm{min}$ per gram, respectively (Figure $3 \mathrm{~B}$ ).

\section{In Vivo ALDH Activity}

Because L. chungangensis CAU $28^{\mathrm{T}}$ showed higher ALDH activity in cheese than in cell culture, cheese was used to determine the effect of ALDH from $L$. chungangensis $\mathrm{CAU} 28^{\mathrm{T}}$ on blood aldehyde levels. In vivo studies were used to determine the acetaldehyde concentrations in the blood of mice treated with cream cheese to confirm the present of acetaldehyde, the byproduct of ethanol metabolism on hangover phase (Verster and Penning, 2010). After $5 \mathrm{~h}$, a marked difference $(P=0.01)$ was observed in acetaldehyde concentrations (Figure 4). The blood acetaldehyde concentration decreased in all mice treated with cheese made with all 5 strains of Lactococcus spp. Cheese made using $L$. chungangensis $\mathrm{CAU} 28^{\mathrm{T}}$ produced the largest decrease in the concentration of aldehyde in mouse blood, with an aldehyde level of $494.3 \mathrm{nmol} / \mathrm{mL}$, followed by $L$. lactis ssp. lactis $\mathrm{KCTC} 3769^{\mathrm{T}}$, L. lactis ssp. cremoris KCCM $40699^{\mathrm{T}}$, L. fujiensis DSM $27937^{\mathrm{T}}$, and L. raffinolactis DSM $20443^{\mathrm{T}}$, which produced blood acetaldehyde concentrations of $504.6,522.5,551.2,559.5 \mathrm{nmol} /$ $\mathrm{mL}$, respectively.

\section{DISCUSSION}

Lactococcus species are lactic acid bacteria that are commonly used as starters in cheese manufacturing; they produce acid and contribute to the ripening process. The main role of starter bacteria is to provide a suitable environment for the bacteria involved in cheese production, in terms of redox potential, $\mathrm{pH}$, and moisture content (Beresford et al., 2001). Lactococcus lactis ssp. lactis and L. lactis ssp. cremoris are used for the production of many kinds of dairy-based fermented milk products, such as cheese, sour cream, and lactic

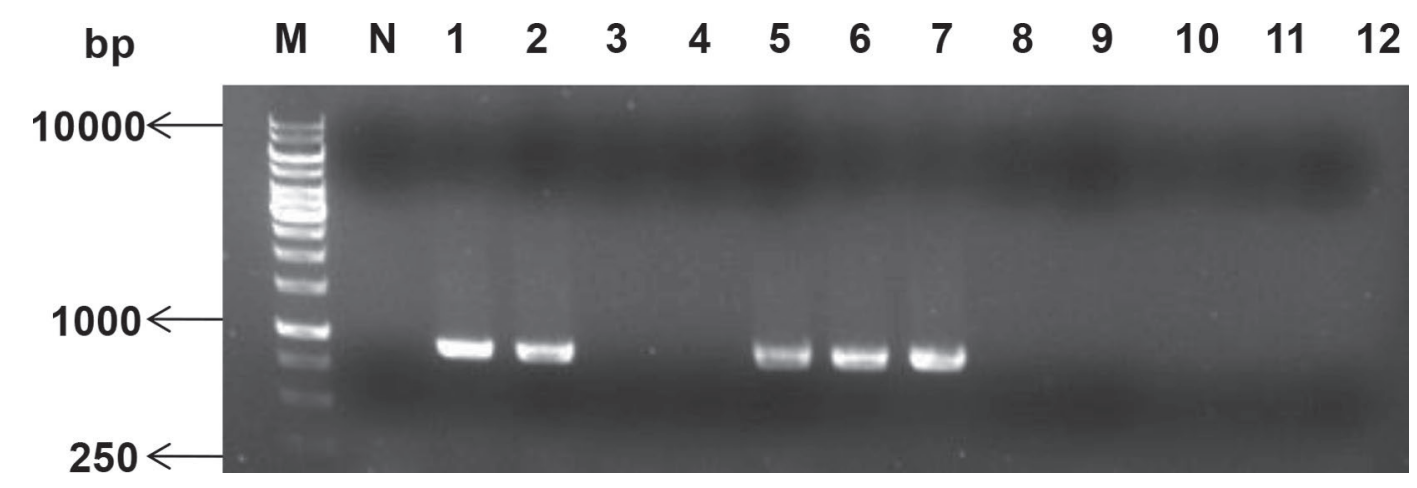

Figure 2. Gel electrophoresis of PCR amplification of the gene for aldehyde dehydrogenase in all Lactococcus species. $\mathrm{M}=\mathrm{marker} ; \mathrm{N}=$ negative control; $1=$ Lactococcus chungangensis CAU $28^{\mathrm{T}} ; 2=$ Lactococcus lactis ssp. lactis KCTC $3769^{\mathrm{T}} ; 3=$ Lactococcus formosensis NBRC $^{\mathrm{T}}$

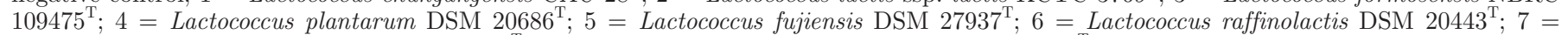
Lactococcus lactis ssp. cremoris KCCM $40699^{\mathrm{T}} ; 8=$ Lactococcus lactis ssp. hordiniae KCTC $3768^{\mathrm{T}} ; 9=$ Lactococcus lactis ssp. tractae $\mathrm{NBRC}^{\mathrm{T}}$ $110453^{\mathrm{T}} ; 10=$ Lactococcus taiwanensis NBRC $109049^{\mathrm{T}} ; 11=$ Lactcooccus garvieae KCTC $3772^{\mathrm{T}} ; 12=$ Lactococcus piscium DSM $^{6} 634^{\mathrm{T}}$. 

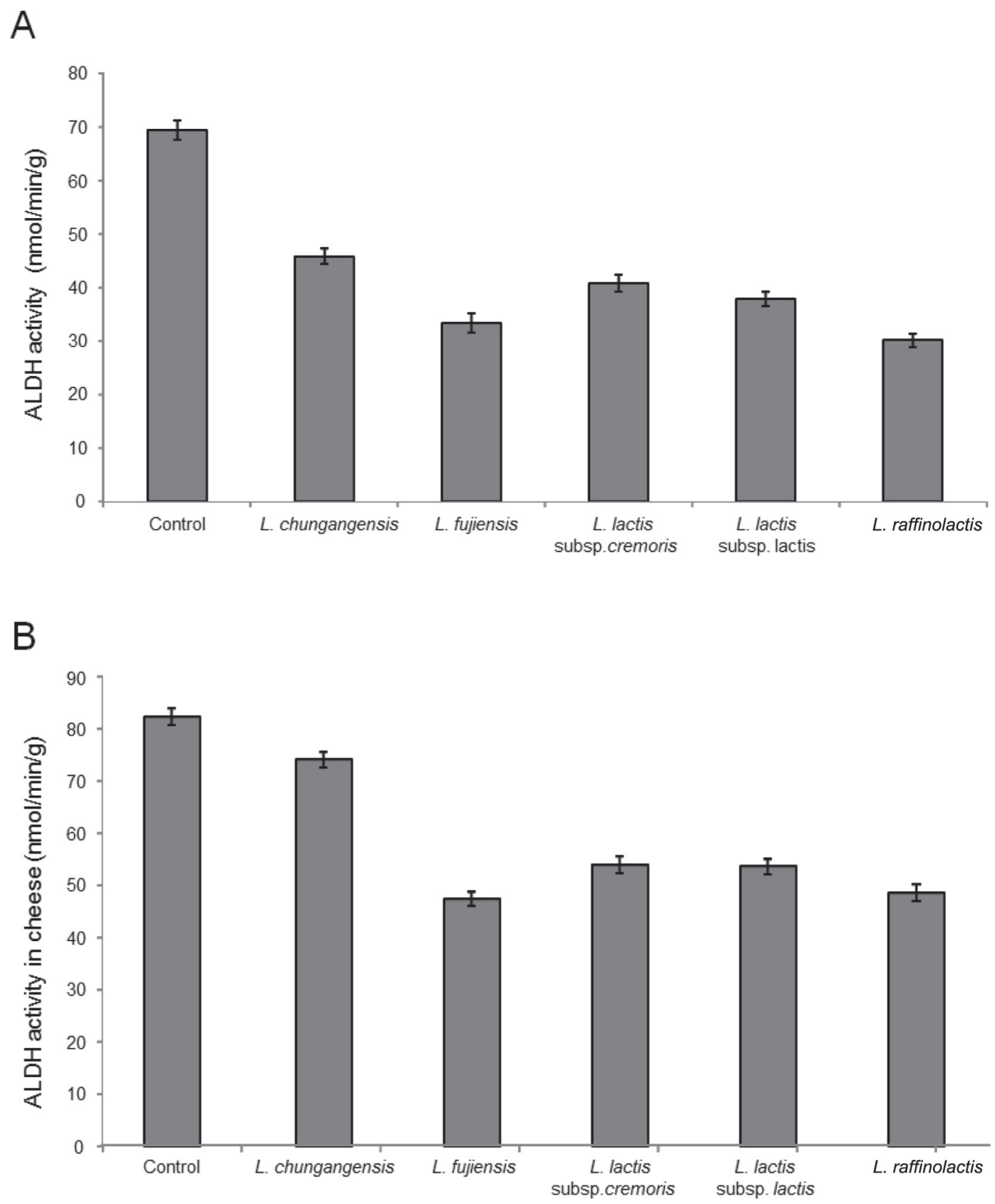

Figure 3. Aldehyde dehydrogenase activity of 5 strains of Lactococcus. (A) Aldehyde dehydrogenase (ALDH) activity of cell culture of Lactococcus spp.; (B) ALDH activity in cheese made with Lactococcus spp.

casein (Klijn et al., 1995). Lactic acid bacteria and bifidobacteria have been extensively studied and widely employed in the field of probiotics, they are also normal components of the intestinal microbiota and have a long tradition of safe application within the food industry (Kociubinski and Salminen, 2006). Extensive research and development activity into probiotics has resulted in a large number of new specialty dairy products, such as drinking yogurt, fermented drinks, sour cream, butter, cream, and cream cheese (Szakály et al., 2007).

Acetaldehydes are unique toxicants that are metabolically detoxified by in vivo oxidation (to acids) and reduced to alcohols (O'Brien et al., 2005). Aldehyde dehydrogenase is the primary enzyme in this process and is involved not only in the formation of acetaldehyde from glucose (Lees and Jago, 1978), but also in a 


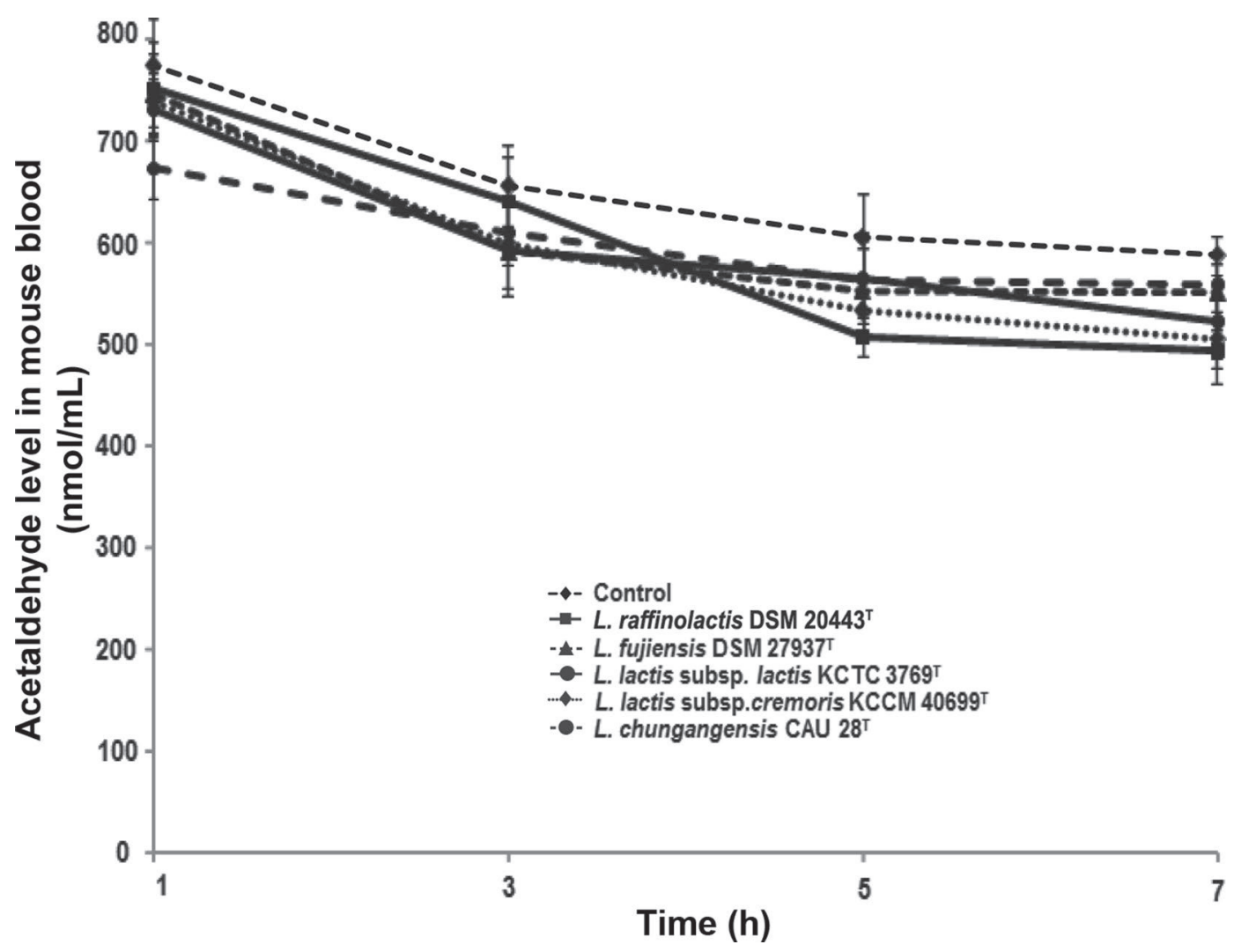

Figure 4. Effects of cream cheese on acetaldehyde concentrations in the blood of mice. Mice were orally administered $22 \%$ ethanol $(2 \mathrm{~g} / \mathrm{kg}$ of BW). Blood alcohol and acetaldehyde concentration were measured at 1, 3, 5, and $7 \mathrm{~h}$ after ethanol administration. The results are expressed as the mean $\pm \mathrm{SD}$ from 5 independent experiments.

variety of biological processes, such as stress responses, in a broad range of bacteria, plant, and animal species (Singh et al., 2013). Aldehyde dehydrogenase has been shown to be related to oxidative stress-associated diseases such as atherosclerosis, cancer, diabetes, and chronic alcohol exposure (Ouadghiri et al., 2005; Jacobs and Marnett, 2010; Yin et al., 2011).

Moreover, ALDH catalyzes the conversion of aldehydes to their corresponding acids by means of a virtually irreversible $\mathrm{NAD}(\mathrm{P})^{+}$-dependent reaction. The ALDH enzymes have been identified in a wide range of organisms, from bacteria to humans (Yoshida et al., 1998); most, if not all, members of the ALDH family are likely present in other mammals. The protein, gene, and cDNA sequences of these enzymes have been reported for more than 50 species of animals, fungi, and bacteria (Kedishvili et al., 1992; Chambliss et al., 1995). In addition, ALDH is the primary enzyme involved in the elimination of alcohol from the body and usually reduces alcohol levels following consumption of alcohol (Zakhari, 2006). Ethanol has been shown to be of clinical significance in gastric metabolism (Julkunen et al., 1985), and the presence of a bac- teriocolonic pathway for ethanol oxidation has been reported (Jokelainen et al., 1996a; Salaspuro, 1998). Via this pathway, intracolonic ethanol is first oxidized by bacterial alcohol dehydrogenase to acetaldehyde (Jokelainen et al., 1996a,b). Acetaldehyde is then oxidized either by colonic mucosal cells or bacterial aldehyde dehydrogenase to acetate (Matysiak-Budnik et al., 1996).

The current study found that cream cheese samples produced with L. chungangensis CAU $28^{\mathrm{T}}$ showed the highest ALDH activity (74.2 nmol/min per gram) compared with those produced with other Lactococcus spp. The aldehyde concentration in the blood of mice was decreased to $494.3 \mathrm{nmol} / \mathrm{mL}$ by application of cream cheese samples produced with $L$. chungangensis CAU $28^{\mathrm{T}}$, corresponding to a high level of ADH activity. Cell cultures and cheese samples produced using $L$. chungangensis CAU $28^{\mathrm{T}}$ were found to decrease aldehyde levels, indicating that cheese made using a starter culture containing $L$. chungangensis $\mathrm{CAU} 28^{\mathrm{T}}$ has potential as a functional food to increase the activity of aldehyde dehydrogenase and to reduce acetaldehyde levels in the blood. 


\section{REFERENCES}

Beresford, T. P., N. A. Fitzsimons, N. L. Brennan, and T. M. Cogan. 2001. Recent advances in cheese microbiology. Int. Dairy J. 11:259-274.

Bourroul, G. 2006. O potencial da cadeia láctea brasileira. Pages 36-48 in Revista Leite e Derivados, Nov./Dec.

Buriti, F. C., H. R. Cardarelli, T. M. Filisetti, and S. M. Saad. 2007. Synbiotic potential of fresh cream cheese supplemented with inulin and Lactobacillus paracasei in co-culture with Streptococcus thermophilus. Food Chem. 104:1605-1610.

Chambliss, K. L., D. L. Caudle, D. D. Hinson, C. R. Moomaw, C. A. Slaughter, C. Jakobs, and K. M. Gibson. 1995. Molecular cloning of the mature NAD-dependent succinic semialdehyde dehydrogenase from rat and human cDNA isolation, evolutionary homology, and tissue expression. J. Biol. Chem. 270:461-467.

Cho, S. L., S. W. Nam, J. H. Yoon, J. S. Lee, A. Sukhoom, and W. Kim. 2008. Lactococcus chungangensis sp. nov., a lactic acid bacterium isolated from activated sludge foam. Int. J. Syst. Evol. Microbiol. 58:1844-1849.

Coutouly, A., A. Riaublanc, M. Axelos, and I. Gaucher. 2014. Effect of heat treatment, final $\mathrm{pH}$ of acidification, and homogenization pressure on the texture properties of cream cheese. Dairy Sci. Technol. 94:125-144.

Fenster, K. M., S. Rankin, and J. Steele. 2003. Accumulation of short n-chain ethyl esters by esterases of lactic acid bacteria under conditions simulating ripening Parmesan cheese. J. Dairy Sci. $86: 2818-2825$.

Fox, P. F., and J. M. Wallace. 1997. Formation of flavor compounds in cheese. Adv. Appl. Microbiol. 45:17-85.

Guinee, T., P. Pudja, and N. Farkye. 1993. Fresh acid-curd cheese varieties. Pages 363-419 in Cheese: Chemistry, Physics and Microbiology. Springer, Berlin, Germany.

Jacobs, A. T., and L. J. Marnett. 2010. Systems analysis of protein modification and cellular responses induced by electrophile stress. Acc. Chem. Res. 43:673-683.

Jokelainen, K., T. Matysiak-Budnik, H. Mäkisalo, K. Höckerstedt, and M. Salaspuro. 1996a. High intracolonic acetaldehyde values produced by a bacteriocolonic pathway for ethanol oxidation in piglets. Gut 39:100-104.

Jokelainen, K., A. Siitonen, H. Jousimies-Somer, T. Nosova, R. Heine, and M. Salaspuro. 1996b. In vitro alcohol dehydrogenase-mediated acetaldehyde production by aerobic bacteria representing the normal colonic flora in man. Alcohol. Clin. Exp. Res. 20:967-972.

Julkunen, R. J., C. Di Padova, and C. S. Lieber. 1985. First pass metabolism of ethanol-A gastrointestinal barrier against the systematic toxicity of ethanol. Life Sci. 37:567-573.

Kedishvili, N. Y., K. Popov, P. Rougraff, Y. Zhao, D. Crabb, and R. Harris. 1992. CoA-dependent methylmalonate-semialdehyde dehydrogenase, a unique member of the aldehyde dehydrogenase superfamily. cDNA cloning, evolutionary relationships, and tissue distribution. J. Biol. Chem. 267:19724-19729.

Klijn, N., A. H. Weerkamp, and W. M. de Vos. 1995. Detection and characterization of lactose-utilizing Lactococcus spp. in natural ecosystems. Appl. Environ. Microbiol. 61:788-792.

Kociubinski, G., and S. Salminen. 2006. Probiotics: Basis, state of the art and future perspectives. In Proc. Functional Food Network General Meeting.
Konkit, M., W. J. Choi, and W. Kim. 2015. Alcohol dehydrogenase activity in Lactococcus chungangensis: Application in cream cheese to moderate alcohol uptake. J. Dairy Sci. 98:5974-5982.

Konkit, M., J.-H. Kim, N. Bora, and W. Kim. 2014. Transcriptomic analysis of Lactococcus chungangensis sp. nov. and its potential in cheese making. J. Dairy Sci. 97:7363-7372.

Lees, G., and G. Jago. 1978. Role of acetaldehyde in metabolism: A review 2. The metabolism of acetaldehyde in cultured dairy products. J. Dairy Sci. 61:1216-1224.

Madkor, S. A., P. Tong, and M. El Soda. 2000. Ripening of Cheddar cheese with added attenuated adjunct cultures of lactobacilli. J. Dairy Sci. 83:1684-1691.

Matysiak-Budnik, T., K. Jokelainen, P. Kärkkäinen, H. Mäkisalo, J. Ohisalo, and M. Salaspuro. 1996. Hepatotoxicity and absorption of extrahepatic acetaldehyde in rats. J. Pathol. 178:469-474.

Menrad, K. 2003. Market and marketing of functional food in Europe. J. Food Eng. 56:181-188.

Nosova, T., K. Jokelainen, P. Kaihovaara, H. Jousimies-Somer, A. Siitonen, R. Heine, and M. Salaspuro. 1996. Aldehyde dehydrogenase activity and acetate production by aerobic bacteria representing the normal flora of human large intestine. Alcohol Alcohol. $31: 555-564$

O'Brien, P. J., A. G. Siraki, and N. Shangari. 2005. Aldehyde sources, metabolism, molecular toxicity mechanisms, and possible effects on human health. Crit. Rev. Toxicol. 35:609-662.

Ouadghiri, M., M. Amar, M. Vancanneyt, and J. Swings. 2005. Biodiversity of lactic acid bacteria in Moroccan soft white cheese (Jben). FEMS Microbiol. Lett. 251:267-271.

Roberfroid, M. B. 2002. Global view on functional foods: European perspectives. Br. J. Nutr. 88(Suppl. 2):S133-S138.

Salaspuro, M. 1998. Bacteriocolonic pathway for ethanol oxidation. Alcohol.: Clin. Exp. Res. 22:772-775.

Silva, T. L., V. R. Souza, A. Pinheiro, C. A. Nunes, and T. V. Freire. 2014. Equivalence salting and temporal dominance of sensations analysis for different sodium chloride substitutes in cream cheese. Int. J. Dairy Technol. 67:31-38.

Singh, S., C. Brocker, V. Koppaka, Y. Chen, B. C. Jackson, A. Matsumoto, D. C. Thompson, and V. Vasiliou. 2013. Aldehyde dehydrogenases in cellular responses to oxidative/electrophilicstress. Free Radic. Biol. Med. 56:89-101.

Szakály, Z., O. Szigeti, A. Máthé, and V. Szente. 2007. Nutrimarketing in the service of functional foods. In Proc. International Developments in Science \& Health Claims, ILSI International Symposium on Functional Foods in Europe.

Tottmar, S. O., H. Pettersson, and K.-H. Kiessling. 1973. The subcellular distribution and properties of aldehyde dehydrogenases in rat liver. Biochem. J. 135:577-586.

Verster, J. C., and R. Penning. 2010. Treatment and prevention of alcohol hangover. Curr. Drug Abuse Rev. 3:103-109.

Yin, H., L. Xu, and N. A. Porter. 2011. Free radical lipid peroxidation: mechanisms and analysis. Chem. Rev. 111:5944-5972.

Yoshida, A., A. Rzhetsky, L. C. Hsu, and C. Chang. 1998. Human aldehyde dehydrogenase gene family. Eur. J. Biochem. 251:549-557.

Zakhari, S. 2006. Overview: How is alcohol metabolized by the body. Alcohol Res. Health 29:245-254. 